wide range of interests which he inspired in his young friends. To his psychological knowledge and insight, and to his sympathy with differing minds, Dr. William Brown has borne eloquent witness in The Times. He was a man of great personal charm and a brilliant conversationalist. His intellectual and æsthetic interests were very wide and led him to seek new experiences and to encourage others to share them. Successive generations of Wykehamists testify to the way in which he stimulated the development of their minds by his own enthusiasm for life.

\section{Mr. Kenneth F. Armstrong}

ThE death of Kenneth Armstrong on January 3, at twenty-five years of age, while on a visit to the Austrian Tyrol with another young and promising Oxford graduate, John Howard, who was an old schoolfellow, is a grievous tragedy. While ski-ing, they encountered an avalanche which seems to have swept Howard to his death, and it appears that Armstrong, in his endeavour to recover his com panion, fell into a ravine, being killed as the result of crashing on a rock.

Armstrong was the son of Dr. E. F. Armstrong and the grandson of Prof. H. E. Armstrong. His death is a personal shock to everyone who knew him, and it is regrettable that chemistry should be deprived of the contribution to its progress so clearly destined to come from his labours. There can be no doubt that, had he lived, he would have done full credit to his scientific ancestry.

Armstrong received his early education at Oundle School, whence he went to Magdalen College, Oxford, in 1927, having been awarded a demyship there. $\mathrm{He}$ gained a first class in the Honour School of Chemistry at Oxford in 1931. After graduating, he was awarded a Julia Henry scholarship and proceeded to Harvard University and commenced work on chlorophyll problems with Prof. J. B. Conant. In the two years spent there, he made a valuable advance in this difficult field, and part of the work has been published in the Journal of the American Chemical Society. Armstrong's extensive knowledge of this subject enabled him to contribute a lucid article on presentdayknowledge ofchlorophyll to Chemistry and Industry.

Soon after his return to Oxford in 1933, Armstrong was eleeted to a Harmsworth senior scholarship at Merton College and was quickly at work on several problems of his own choice. Among these were : the nature of the colouring matter of the red moth; the identity of the glucoside in the Japanese laurel (Aucubine); and the configuration of the cyclic polyalcohols, particularly quebrachol. Recently, in collaboration with Prof. R. Robinson, some work on the oxidation effects of selenium dioxide was published. Armstrong recently collaborated with his father in producing a new edition of the well-known books on the simple carbohydrates and the glycosides.

His friends will ever remember with respect and admiration Armstrong's unfailing kindliness on all occasions. His lamented death deprives the Oxford school of organic chemistry of one of the most notable of the younger generation of research students.

\section{Dr. Eleanor Hull}

WE regret to record the death of Miss Eleanor Henrietta Hull, folklorist and Erse scholar, which took place at the age of seventy-five years, on January 14 , at Wimbledon.

Miss Hull was the daughter of Prof. Edward Hull, and was educated at Alexandra College and the Royal College of Science, Dublin. She studied Celtic and allied subjects under Pedersen, Kuno Meyer and R. Flower. An enthusiast for the study of Irish history and letters, she added sound scholarship to the movement for the revival of Erse and the rekindling of pride in Irish tradition. Apart from her own literary work, this took practical form in the foundation in 1899, with the assistance of Prof. York Powell, of the Irish Texts Society. As honorary secretary of the Society she enlisted the services of the foremost Erse scholars of the day, and was largely responsible for the publication of a number of valuable and important early Irish manuscripts. Miss Hull was at one time secretary of the Royal Asiatic Society. She had served as president of the Irish Literary Society of London and was a member of the Council of the Folklore Society.

Among her contributions to Irish studies her work on the Cuchulain Saga (1898) will always hold first place; but as a folklorist her "Folklore of the British Isles" (1928), in bringing some sort of system and order to the treatment of a mass of somewhat chaotic material, runs it close. Among other works worthy of note were her "Pagan Ireland and Early Christian Ireland" (1904), "A Text-Book of Irish Literature" (1906-7), "Cuchulain, the Hound of Ulster" (1909), and a "History of Ireland and Her People" (1926, 1931) in two volumes.

WE regret to announce the death of Arthur Lionel Pedder, on December 15, at the age of sixty-six years. He was mathematical tutor at Magdalen College, Oxford, from 1891 until 1925. He went to the College as a demy in 1886, and was elected fellow in 1894. Pedder was a very good teacher and was remembered with gratitude and affection by his pupils. He was one of the old-fashioned people who valued the educational training given by the curriculum and examinations of the old mathematical school as one of the best preparations for after-life; and was quite out of sympathy with the new system which, in his opinion, was of little or no use, except for those who intended to be professional mathematicians.

WE regret to announce the following deaths :

Mr. F. J. Blight, fellow of the Royal Society of Edinburgh and formerly chairman and managing director of Messrs. Charles Griffin and Co., Ltd., publishers of many scientific and technical works, on January 27, aged seventy-six years.

Dr. Michael Grabham, author of numerous books and papers on the natural history of Madeira, where he had lived for some seventy years, on January 28 , aged ninety-five years. 